\title{
Inhibitory Effects of Different Varieties of Sweet Potato (Ipomoea batatas $L$.) Tubers Extracts on Lipoxygenase Activity
}

\author{
Sendangratri ${ }^{1}$, Rosita Handayani ${ }^{1}$, Berna Elya ${ }^{1, *}$
}

Sendangratri ${ }^{1}$, Rosita Handayani ${ }^{1}$, Berna Elya ${ }^{1, *}$

'Laboratory of PharmacognosyPhytochemistry, Faculty of Pharmacy, Universitas Indonesia, Depok, West Java, INDONESIA.

\section{Correspondence}

Berna Elya

Department of Pharmacognosy-

Phytochemistry, Faculty of Pharmacy,

Universitas Indonesia, Depok, INDONESIA.

E-mail: berna.elya@farmasi.ui.ac.id

History

- Submission Date: 16-02-2019;

- Review completed: 12-04-2019;

- Accepted Date: 24-05-2019.

DOI : 10.5530/pj.2019.11.185

Article Available online

http://www.phcogj.com/v11/i6

\section{Copyright}

(C) 2019 Phcogj.Com. This is an openaccess article distributed under the terms of the Creative Commons Attribution 4.0 International license.

\begin{abstract}
Background: Sweet potatoes (/pomoea batatas L.) with purple, orange and white varieties can be differentiated by their skin and flesh tubers' colors. Research on anti-inflammatory activity of this plant is still limited although has been used traditionally. Objective: This study aimed to determine $\mathrm{IC}_{50}$ value of sweet potato tubers extracts in inhibiting lipoxygenase activity. Methods: Dried tubers of sweet potato were macerated with ethanol $70 \%$. Each extracts were tested for soybean lipoxygenase inhibitory activity, phytochemical screening and total flavonoid contents. $\mathrm{IC}_{50}$ value and total flavonoid contents obtained from each extracts were analyzed statistically. Results: $I C_{50}$ value of purple, orange and white sweet potato tubers extracts are $46.09,52.12$ and $63.69 \mu \mathrm{g} / \mathrm{mL}$ respectively. Each extracts contain alkaloids, flavonoids, saponins, tannins and glycosides. Total flavonoid contents in purple, orange and white sweet potato extracts are $8.45 \pm 0.41 ; 7.57 \pm 0.03$; and $6.12 \pm 0.14 \mathrm{mgQE} / \mathrm{g}$ extract respectively. Conclusion: Total flavonoid contents and $\mathrm{IC}_{50}$ values of each extracts are strongly correlated and inversely proportional with significance value of 0.026 and correlation value of -0.999 which indicate that the higher total flavonoid contents, the stronger inhibitory activity.
\end{abstract}

Key words: Anti-inflammatory, Ipomoea batatas L., Lipoxygenase, Sweet potato tubers, Total flavonoid contents.

\section{INTRODUCTION}

Over the past few decades, researches for medicines derived from plants has been widely carried out. Although most researches are still focused on herbs, vegetables and fruits also have medicinal properties. Ipomoea batatas L., commonly known as sweet potato, is root vegetable which is often consumed as food. ${ }^{1}$ The value of production and consumption of sweet potato in Indonesia in 2016-2019 is growing every year. Production of sweet potatoes in Indonesia in 2016-2017 experienced growth of $17.88 \%$, while in $2018-2019$ predicted growth of 4.08 and $2.39 \%$. Sweet potato consumption in Indonesia in $2016-2017$ has increased by $12.46 \%$, while in 2018-2019 is predicted to increase by 5.97 and $3.98 \% .^{2}$

Sweet potato plays an important role as a source of energy and phytochemicals in human nutrition. This plant can have properties such as medicine and various parts of this plant are used in traditional medicine. In Kagawa region of Japan, various sweet potato varieties are consumed directly or raw to treat anemia, hypertension and diabetes. ${ }^{3}$ Sweet potato tubers are also used to treat type 2 diabetes by tribes in Ghana ${ }^{4}$ and in the treatment of oral inflammation or infection in Brazil. ${ }^{5}$

Inflammation is the body's response which includes blood vessels, body cells, proteins and other mediators to eliminate the initial causes of cell injury, as well as damaged cells and necrotic tissues. ${ }^{6}$ In addition, the respon is also intended to initiate cell and tissue repair. Inflammation causes local symptoms such as edema (turgor), burning (calor), redness (rubor) and pain (dolor). Inflammatory causes can be in the form of foreign microorganisms, mechanical trauma, chemical mediators, or physical factors. One of the chemical mediators in the body is the leukotrien synthesized from arachidonic acid with the help of 5-Lipoxygenase (5-LOX). Leukotrien plays a major role in a number of inflammatory and immune responses associated with several diseases such as asthma, atherosclerosis and cancer. ${ }^{8}$ Therefore, inhibition of leukotriene biosynthesis by blocking 5-LOX activity has been recommended for therapeutic use. ${ }^{9}$

Inhibition of 5-LOX activity can be through various ways, one of which is with antioxidant compounds that will reduce ferric iron ions $\left(\mathrm{Fe}^{3+}\right)$ on the active site of the enzyme so that it becomes inactive form..$^{10}$ From the results of other studies that have been done explain that 5-LOX inhibitors are found in many classes of phenolic compounds. The most potent phenolic compounds as 5-LOX inhibitors are flavonoids that work by reducing ferric $\left(\mathrm{Fe}^{3+}\right)$ to ferro $\left(\mathrm{Fe}^{2+}\right) \cdot{ }^{11}$ Anthocyanins which belong to flavonoid are found in purple sweet potato tubers. Luteolin is also a flavonoid found in orange and purple sweet potato tubers. ${ }^{1}$ Purple, orange and white sweet potato has an IC50 antioxidant of $93.34 \pm 1.9 ; 59.68 \pm 12.44$ and $34.28 \pm 4.96 \% .^{12}$ Total flavonoid content of purple, orange and white sweet potato tubers is respectively $2.53 \pm 0.01 ; 2.45 \pm 0.03$; and $0.68 \pm 0.02 \mathrm{gQE} / 100 \mathrm{~g}$ extracts. ${ }^{13,14}$

Cite this article: Sendangratri, Handayani R, Elya B. Inhibitory Effects of Different Varieties of Sweet Potato (Ipomoea batatas L.) Tubers Extracts on Lipoxygenase Activity. Pharmacog J. 2019;11(6):1195-8. 
Based on the background above, the author intends to conduct research on the inhibition of lipoxygenase activity by sweet potato tubers extract with purple, orange and white varieties in Indonesia. Furthermore, phytochemical screening and determination of total flavonoid contents were also performed to each extracts. In addition, the data obtained are analyzed using SPSS version 22.0 to determine the relationship between $\mathrm{IC}_{50}$ value and total flavonoid content.

\section{MATERIALS AND METHODS}

\section{Materials}

The extract used in this study was produced from the simplicia of sweet potato tuber (Ipomoea batatas L.) with varieties of purple, orange and white obtained from Depok, West Java, Indonesia. The standard for lipoxygenase activity inhibition test used apigenin (Sigma Aldrich-10798, USA) and the standard for total flavonoid contents used quercetin (Sigma Aldrich-Q4951, USA). Other materials and reagents were soybean lipoxygenase (Sigma Aldrich-L7395, USA), linoleic acid (Sigma Aldrich-1376, USA), aqua demineralisata (Brataco, Indonesia), 96\% ethanol (Brataco, Indonesia), ethanol $\mathrm{P}$ (Brataco, Indonesia), DMSO (Brataco, Indonesia) and aqua destilata (Brataco, Indonesia).

\section{Extraction}

The extraction was carried out by maceration method. The ratio used between the dried tubers and the solvent is $1: 10$. The solvent used is $70 \%$ ethanol. The immersion process was carried out during the first $6 \mathrm{~h}$ with occasional stirring, then allowed to stand for $18 \mathrm{~h}$. Then, the filtration process was carried out to produce filtrate or macerate. This maceration stage was repeated three times. Then, each maserate was evaporated to remove the solvent residue with rotary vacuum evaporator or waterbath until it turned to viscous extracts.

\section{Lipoxygenase activity inhibitory test}

Preliminary test consisted of optimization of linoleic acid as substrate with various concentrations $(100,200,300,400,500 \mu \mathrm{M})$. The lipoxygenase activity inhibition test was performed by reacting 50 $\mu \mathrm{L}$ of apigenin (Sigma-Aldrich) or sample solution (with various concentrations), $1650 \mu \mathrm{L}$ of $0.2 \mathrm{M}$ borate buffer ( $\mathrm{pH} 9.0$ ) and $1000 \mu \mathrm{L}$ of a linoleic acid substrate (Sigma-Aldrich) $(300 \mu \mathrm{M})$. The solution was incubated for $10 \mathrm{~min}$ at $25^{\circ} \mathrm{C} .300 \mu \mathrm{L}$ of lipoxygenase solution $\left(1000\right.$ units $/ \mathrm{mL}$ ) was added and incubated for $15 \mathrm{~min}$ at $25^{\circ} \mathrm{C}$. Then, $1000 \mu \mathrm{L}$ of methanol as stop solution was added. Finally, the solution's absorbance was measured by UV-Vis spectrophotometer at $234 \mathrm{~nm}$. Analysis was done in triplicate. The procedures were referred to Kemal et al. (1987) with few modifications.

Inhibition of lipoxygenase activity calculated using the following equation: Lipoxygenase Inhibitory $(\%)=((\mathrm{A}-\mathrm{B})-(\mathrm{C}-\mathrm{D})) /((\mathrm{A}-\mathrm{B})) \times 100 \%$

$\mathrm{A}=$ Absorbance of blank solution with enzyme

$\mathrm{B}=$ Absorbance of blank solution without enzyme

$\mathrm{C}=$ Absorbance of standard or sample solution with enzyme

$\mathrm{D}=$ Absorbance of standard or sample solution without enzyme

The result was expressed as $\mathrm{IC}_{50}$ value $(\mu \mathrm{g} / \mathrm{mL})$ and obtained by Microsoft Office Excel.

\section{Phytochemical screening}

The extracts were subjected to phytochemical screening for the detection of following compounds; terpenoids, glycosides, flavonoids, alkaloids, tannins, anthraquinones and saponins. The procedures were referred to Indonesian Herbal Pharmacopoeia (2011).

\section{Determination of total flavonoid contents}

Total flavonoid contents was measured with $\mathrm{AlCl}_{3}$ colorimetry method. Prepared samples $(0.5 \mathrm{~mL})$ by reacting $1.5 \mathrm{~mL}$ of ethanol $\mathrm{P}(\mathrm{v} / \mathrm{v}), 0.1 \mathrm{~mL}$ of $10 \%$ aluminum chloride $(\mathrm{w} / \mathrm{v}), 0.1 \mathrm{~mL}$ of $1 \mathrm{M}$ sodium acetate and 2.8 $\mathrm{ml}$ of distilled water. The mixture solution were incubated at room temperature for $30 \mathrm{~min}$. The absorbance was measured at wavelength 430 $\mathrm{nm}$. The analysis was done in triplicate. Quercetin was used as a standard with the same treatment as the samples for the calibration curve. The total flavonoid contents was reported as total quercetin equivalent per g extract (mgQE/g extract). The procedures were referred to Indonesian Herbal Pharmacopoeia (2011).

\section{Statistical analysis}

Statistical analysis was performed to determine the correlation of $\mathrm{IC}_{50}$ values with total flavonoid contents of each extracts. Analysis was done with SPSS version 22.0 through two types of tests. The first test was normality test to get the distribution of data in a group. The amount of datas in this study were less than 30 , so the result of the analysis chosen was by Shapiro-Wilk method. Then, the correlation test with Pearson method was carried out if the results showed normal distribution.

\section{RESULTS AND DISCUSSIONS}

\section{Extraction}

Each simplicia is extracted by maceration method. The solvent used for maceration is $70 \%$ ethanol. According to the Indonesian Herbal Pharmacopoeia (2011), 70\% ethanol is a solvent commonly used for the extraction of simplicia if not stated otherwise. Extraction was carried out as many as 3 repetitions with a comparison of simpliciasolvent 1:10. The filtrate or macerate was evaporated with waterbath or rotary evaporator to remove the remaining solvent until a dried extract was obtained. The dried extract was then weighed and the results were obtained as shown in Table 1.

\section{Lipoxygenase activity inhibitory test}

The inhibition of lipoxygenase activity aimed to compare $\mathrm{IC}_{50}$ values between samples and standards. Apigenin was used as a standard or positive control because it belongs to the class of flavonoid compounds which are potent inhibitors of lipoxygenase activity and has free hydroxyl $(\mathrm{OH})$ group which can reduce $\mathrm{Fe}^{3+}$ on the active side of the enzyme, so that the substrate will not oxidized to form products. ${ }^{10}$ In addition, based on previous study, $\mathrm{IC}_{50}$ value of apigenin was $7.51 \mu \mathrm{M}$ $(2.03 \mu \mathrm{g} / \mathrm{mL})^{15,16}$ which showed that apigenin could inhibit lipoxygenase activity. The $\mathrm{IC}_{50}$ apigenin value in this study was $7.69 \mu \mathrm{M}(2.08 \mu \mathrm{g} / \mathrm{mL})$ which showed similarities with the results of previous study.

Inhibition of lipoxygenase activity by extracts was carried out using an optimized linoleic acid substrate of $300 \mu \mathrm{M}$ and a lipoxygenase solution of $1000 \mathrm{U} / \mathrm{mL}$. Inhibition of lipoxygenase activity by purple, orange and white sweet potato tubers extracts were done at concentrations of 2000 , $4000,6000,8000$ and $10.000 \mu \mathrm{g} / \mathrm{mL}$ (final concentrations of $25,50,75$, $100,125 \mu \mathrm{g} / \mathrm{mL}$ ). The selection of this concentration varieties was based on experiments that have been conducted several times by researchers.

Based on the results obtained, purple sweet potato extract had the lowest $\mathrm{IC}_{50}$ value of $46.09 \mu \mathrm{g} / \mathrm{mL}$, while orange and white sweet potato extracts were 52.12 and $63.69 \mu \mathrm{g} / \mathrm{mL}$ respectively. The percentage of inhibition of lipoxygenase activity was directly proportional to the concentration of the extract tested, so the higher the concentration of the extract, the stronger the inhibitory activity. When compared with apigenin as standard (Figure 1), the $\mathrm{IC}_{50}$ value of apigenin was lower than the three extracts. This showed that apigenin as a nature compound had better activity than the three extracts in inhibiting lipoxygenase activity. 


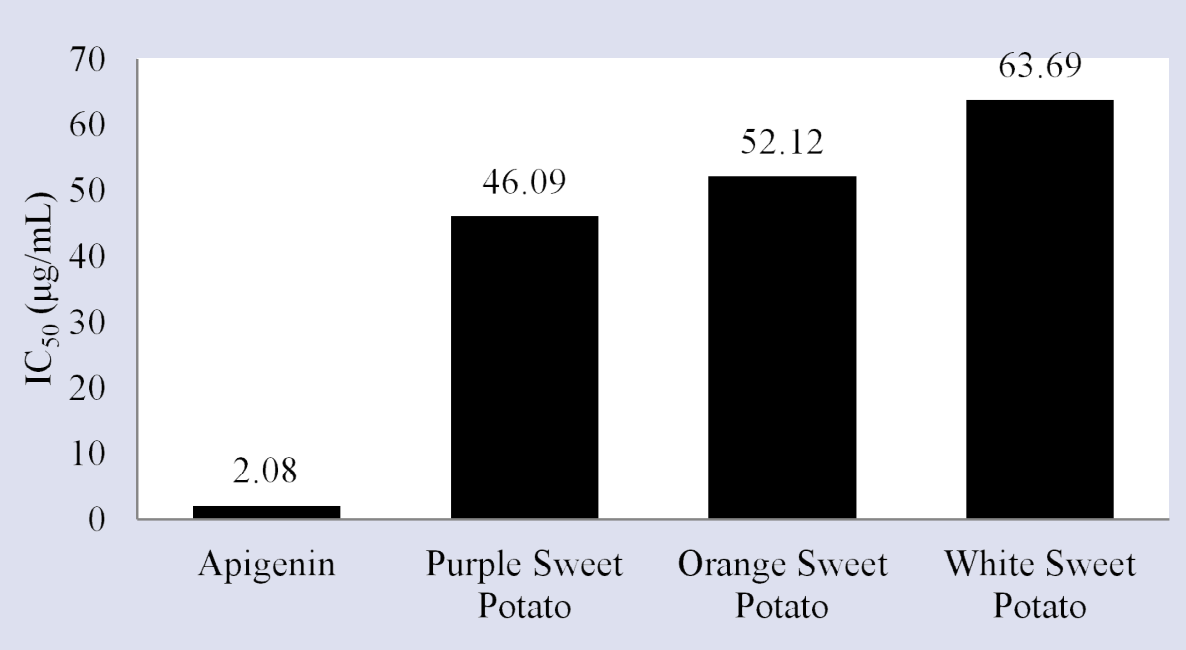

Figure 1: Results of inhibition of lipoxygenase activity by standard and extracts.

Table 1: Results of extract's yield.

\begin{tabular}{ccccc}
\hline Extract & $\begin{array}{c}\text { Simplicia } \\
\text { Weight }(\mathbf{g})\end{array}$ & $\begin{array}{c}\text { Solvent Total } \\
\text { Volume (L) }\end{array}$ & $\begin{array}{c}\text { Extract } \\
\text { Weight (g) }\end{array}$ & $\begin{array}{c}\text { Yield } \\
(\%)\end{array}$ \\
\hline Purple & 800.0 & $3 \times 8.0$ & 198.96 & 24.87 \\
Orange & 620.0 & $3 \times 6.2$ & 174.87 & 28.20 \\
White & 760.0 & $3 \times 7.6$ & 164.46 & 21.63 \\
\hline
\end{tabular}

Table 2: Phytochemical screening of each extracts.

\begin{tabular}{cccccccc}
\hline \multirow{2}{*}{ Extract } & \multicolumn{7}{c}{ Results } \\
\cline { 2 - 7 } & Alkaloids & Flavonoids & Terpenes & Tannins & Saponins & Glycosides & Antraquinons \\
\hline Purple & + & + & - & + & + & + \\
Orange & + & + & - & + & + & + \\
White & + & + & - & + & + & + \\
\hline
\end{tabular}

\section{Phytochemical screening}

Phytochemical screening showed presence of alkaloids, flavonoids, tannins, saponins glycosides and negative to terpenes and antraquinons. The results shown in Table 2 .

\section{Determination of total flavonoid contents}

Quercetin levels were calculated as total flavonoid contents in the sample. From the calculation of quercetin standard curve, there was a linear correlation between absorbance and concentration with linear regression equation of $y=0.0945 x+0,1245$ and relation coefficient value of $(r)=0.9999$. Based on the results of this test showed that in $1 \mathrm{~g}$ of purple sweet potato extract contained $8.45 \pm 0.41 \mathrm{mgQE}$. Whereas in $1 \mathrm{~g}$ of orange and white sweet potato extract contained $7.57 \pm 0.03$ and $6.12 \pm 0.14 \mathrm{mgQE}$ respectively. From these results, purple sweet potato tuber extract had the highest total flavonoid content followed by orange and white sweet potato. Thus, it can be expected that compounds that play a role in inhibiting lipoxygenase activity by purple, orange and white sweet potato extract are flavonoids because they have the highest to the lowest order which equals to the $\mathrm{IC}_{50}$ value.

\section{Statistical analysis}

In the results of the normality test (Table 3 ), the significance value indicated by Sig. on the three variables showed $\mathrm{p}>0.05$ which means that $\mathrm{H}_{0}$ is accepted or the data distribution is normal.

From the results of the above normality test, the correlation test can be done with Pearson because it meets the requirements if the data distribution is normal. Correlation tests were conducted to determine the degree of closeness and direction of the relationship between variables. The test results (Table 4) showed a significance value of 0.026 which means $<0.05, \mathrm{H} 1$ is accepted or there is a relationship between the variables of total flavonoid levels and $\mathrm{IC}_{50}$. Pearson correlation value showed -0.999 which means that the relationship is strong and inversely proportional because it is close to 1.000 and there is a "-" sign. From the test results above, it can be concluded that there is a strong relationship and inversely proportional between the total flavonoid levels and $\mathrm{IC}_{50}$, or it can be said that the higher the total flavonoid contents, the lower the $\mathrm{IC}_{50}$ or the stronger the inhibitory activity.

\section{CONCLUSION}

Based on the results of research conducted on the three extracts of Ipomoea batatas L., it can be concluded that $\mathrm{IC}_{50}$ values of sweet potato tuber extracts of purple, orange and white varieties against inhibition of lipoxygenase activity were $46.09 ; 52.12$; and $63.69 \mu \mathrm{g} /$ $\mathrm{mL}$ respectively. The group of compounds contained in sweet potato, purple and white varieties of sweet potato tuber extracts are alkaloids, flavonoids, tannins, saponins and glycosides. Total flavonoid levels of sweet potato, purple, orange and white sweet potato tuber extracts are $8.45 \pm 0.41 ; 7.57 \pm 0.03$; and $6.12 \pm 0.14 \mathrm{mgQE} / \mathrm{g}$ extract respectively. Total flavonoid levels and $\mathrm{IC}_{50}$ values of the three extracts are strongly correlated and inversely proportional to the significance value of 0.026 and the correlation of -0.999 which indicates that the higher the total flavonoid contents, the stronger the inhibitory activity. 
Table 3: Normality test results with Shapiro-Wilk.

\begin{tabular}{cc}
\hline Variable & Sig. \\
\hline Total Flavonoid Contents & 0.732 \\
IC $_{50}$ & 0.656 \\
Extract & 1.000 \\
\hline
\end{tabular}

Table 4: Correlation test results with pearson.

\begin{tabular}{llll}
\hline & & TFC & $I_{50}$ \\
\hline Total Flavonoid & Pearson & 1 & -0.999 \\
Contents & Correlation & & 0.026 \\
& Sig. (2-tailed) & & 1 \\
$\mathrm{IC}_{50}$ & $\begin{array}{l}\text { Pearson Correlation } \\
\text { Sig. (2-tailed) }\end{array}$ & -0.999 & - \\
\hline
\end{tabular}

\section{ACKNOWLEDGEMENT}

The authors would like to acknowledge the financial support of Publikasi Internasional Terindeks untuk Tugas Akhir Mahasiswa (PITTA) from DRPM UI.

\section{CONFLICTS OF INTEREST}

We declare that we have no conflicts of interest.

\section{REFERENCES}

1. Woolfe JA. Sweet potato-past and present. In: Sweet potato: An untapped food resource. London: Cambridge University Press. 1992.

2. Pusat Data dan Sistem Informasi Kementerian Pertanian Republik Indonesia. Outlook Komoditas Pertanian Sub Sektor Tanaman Pangan. Jakarta: Kementerian Pertanian Republik Indonesia. 2017.

3. Ludvik B, Neuffer B, Pacini G. Efficacy of Ipomoea batatas (Caiapo) on diabetes control in type 2 diabetic subjects treated with diet. Diabetes Care. 2004;27:436-40.
4. Abel C, Busia K. An exploratory ethno botanical study of the practice of herbal medicine by the Akan peoples of Ghana. Altern Med Rev. 2005;10:112-22.

5. Pochapski MT, Fosquiera EC, Esmerino LA, Santos EB, Farago PV, Santos FA Phytochemical screening, antioxidant and antimicrobial activities of the crude leaves' extract from Ipomoea batatas (L.) Lam. Pharmacogn Mag. 2011;7:165-70.

6. Kumar V, Abbas A, Aster J. Robbins and cotran pathologic basis of disease (9th ed.). Philadelphia: Elsevier saunders. 2015

7. Sherwood L. Human physiology: From cells to systems (7th ed.). California: Brooks/Cole. 2010

8. Duroudie NP, Tulah AS, Sayers I. Leukotriene pathway genetics and pharmacogenetics in allergy. Allergy. 2009;64:823-39.

9. Ribeiro D, Freitas M, Tome SM, Silva AM, Porto G, Cabrita EJ, et al. Inhibition of LOX by flavonoids: a structure-activity relationship study. Eur J Med Chem. 2014;72:137-45.

10. Werz O, Steinhilber D. Development of 5-lipoxygenase inhibitors - lessons from cellular enzyme regulation. Biochem Pharmacol. 2005;70:327-33.

11. Sadik $C D$, Sies $H$, Schewe T. Inhibition of 15-lipoxygenases by flavonoids: structure-activity relations and mode of action. Biochem Pharmacol. 2003;65:773-781.

12. Fidrianny I, Windyaswari AS, Wirasutisna KR. DPPH scavenging activity of various extracts of sweet potatoes with varying tubers colors. IJRPS. 2013;3(2):133-45

13. Fidrianny I, Suhendy $H$, Insanu M. Correlation of phytochemical content with antioxidant potential of various sweet potato (Ipomoea batatas) in West Java, Indonesia. Asian Pacific Journal of Tropical Biomedicine. 2018:8(1):25-30.

14. Kementerian Kesehatan Republik Indonesia, Direktorat Jenderal Bina Kefarmasian dan Alat Kesehatan. (2011). Suplemen // farmakope herbal indonesia edisi I. Jakarta: Direktorat Jenderal Bina Kefarmasian dan Alat Kesehatan.

15. Nabilah Elya B, Djajadisastra J. Lipoxygenase inhibitory assay of averrhoa carambola L. leaves extract. International Journal of Chemtech Research. 2017; 10(1):342-47.

16. Kemal C, Louis-Flamberg P, Krupinski-Olsen R, Shorter A. Reductive inactivation of soybean lipoxygenase 1 by catechols: a possible mechanism for regulation of lipoxygenase activity. Biochemistry. 1987;26(22):7064-72.

Cite this article: Sendangratri, Handayani R, Elya B. Inhibitory Effects of Different Varieties of Sweet Potato (/pomoea batatas L.) Tubers Extracts on Lipoxygenase Activity. Pharmacog J. 2019;11(6):1195-8. 